\title{
The tale of obesity: challenges and solutions
}

\author{
Samuel Halim
}

\begin{abstract}
Abstrak
Obesitas telah menyerang dengan kekuatan penuh dan dampaknya adalah meningkatnya prevalensi di seluruh dunia seiring dengan meningkatnya angka kematian dan penyakit yang berhubungan dengan obesitas. Faktor genetik, hormonal dan lingkungan berinteraksi satu sama lain menyebabkan obesitas. Diet rendah kalori dan gaya hidup aktif secara fisik adalah cara utama untuk menangani obesitas. Penanganan tambahan adalah melalui intervensi farmakologis, menggunakan dua obat baru, yaitu cyclobutane methanamine $\mathrm{HCl}$ dan tetrahidrolipstatin, yang potensial untuk pengaturan obesitas. Cara terakhir untuk memecahkan masalah ini adalah dengan melakukan pembedahan. Akhir kata, pasien harus berkonsultasi dengan dokternya dalam memutuskan metode mana yang paling efektif untuk mencari solusi terhadap obesitas. (Med J Indones 2003; 12: 53-62)
\end{abstract}

\begin{abstract}
Obesity has struck with all its might and the results are the increased world-wide prevalence along with increased mortality rate and other obesity-related diseases. Genetic, hormonal and environmental factors interact to cause obesity. Very low calorie diet and physically active lifestyle are the primary means to treat obesity. Additional intervention is by pharmacological treatment, using two new drugs, namely cyclobutane methanamine $\mathrm{HCl}$ and tetra hidrolipstatin that are potential for the management of obesity. Another way to solve this problem is by performing a surgery. In conclusion, patients should consult their physicians in order to decide which methods are the most effective to find a solution to combat obesity. (Med J Indones 2003; 12: 53-62)
\end{abstract}

Keywords: epidemic, genetic, leptin, cardiovascular disease, diabetes, gastric bypass, laparoscopic banding

Obesity used to be considered as merely abnormality of body weight, composition, and metabolism. However, it seems that this notion have changed. Recently, obesity has been regarded as a disease for individuals, and an epidemic for the community, following its increasing prevalence worldwide. In addition, obesity worsens many other diseases such as hypertension, type 2 diabetes, and coronary heart disease (CHD). The tale of obesity is yet about to be revealed as scientists have been trying to uncover this mystery of obesity for years, and the number of studies on obesity are growing rapidly recently. The discovery of whole understanding of this disease is urgent, since it is like a time bomb, ready to explode at any time.

\section{OBESITY AS AN EPIDEMIC}

Today, more than $22 \%$ of the population in the United States are considered obese, which means 1 out of 4

Third year student of the Faculty of Medicine, University of Indonesia, Jakarta, Indonesia people is obese; the prevalence increased by $30 \%$ between 1980 and 1994. ${ }^{1,2}$ More dramatic statistic was reported by the Centers for Disease Control and Prevention (CDC), that there has been a 57\% increase in obesity in the US since $1991 .^{3}$ As many as 300,000 Americans now die each year from obesity-related illness. Similar but less prominent case occurred in Europe, especially in England where 58\% of adults are overweight, among them $20 \%$ are obese (1 out of 5 people). ${ }^{3}$ According to UK's National Audit Office (NAO) the number of people who are obese in England has tripled over the last 20 years, and if the trend continues, one in four will be obese by 2010 . International Diabetes Institute (IDI) found that $40 \%$ of Australians are considered overweight and another $20 \%$ are obese. ${ }^{4}$ As stated above, the prevalence of obesity in developed countries are high and tends to increase in the coming years.

It is suspected that the high prevalence are to be found in industrialized nations only, but apparently it is not. This epidemic problem has reached developing countries such as those in Asia Pacific as well, 
although it is not as high as in developed countries. In Malaysia, $4.7 \%$ of men and $7.7 \%$ of women were reported to be obese in 1995, a further $20 \%$ were considered overweight. ${ }^{2}$ These findings are almost similar to those in Japan, Hong Kong and China, with higher percentage in Mauritius and Western Samoa. Although Indonesia does not have too many researches on obesity, the prevalence increase was seen in Jakarta, from $4.2 \%$ in 1982 to $10.9 \%$ in $1992 .{ }^{6}$

Even more alarming is the rising trend of obesity and overweight recorded not only in adults but also in children in the Asia Pacific and Australian region. ${ }^{2,7}$ Up to $30 \%$ of adolescents and 20\% of juvenile Australians are now overweight or obese. This has major implications for medical practice in both primary and secondary care, now and in the future.

\section{ACQUAINTANCE WITH OBESITY}

Obesity implies an excess of body fat, which can be measured accurately by sophisticated methods including underwater weighing, electrical bioimpedance, dual energy X-ray absorpstiometry, magnetic resonance imaging (MRI), and computerized axial tomography (CT) scanning., ${ }^{2,8}$ They do differ in their accuracy and availability. However, the accuracy and merit of each method is beyond the scope of this paper. Although the usage of these methods are increasing, they often still considered to be too expensive and time consuming.

A widely and easy-to-use method to address obesity is by counting the body mass index (BMI), defines as body weight in kilograms divided by the square of body height in meters. Body mass index has been used for about 20 years, ${ }^{8}$ and still one of the most favorable way of classifying the degree of weight. Several weight classification guidelines based on BMI have been recommended by experts, including the World Health Organization (WHO). However, these represent somewhat arbitrary cut-off values, and apply largely to Caucasians. ${ }^{2}$ In February 2000, WHO recommended a new criteria based on BMI to be used to define obesity in Asians. ${ }^{10}$ Table 1 shows the comparison of classification of weight based on BMI in Caucasian and Asian adults.

Although generally used, BMI is not a perfect standard to body weight classification, and its mathematical complexity can prevent its use. Further more, BMI is sometimes misleading, since BMI does not indicate body mass composition, especially fat. ${ }^{11}$
Two persons with the same BMI, does not represent similar body composition; one person might have more fat than the other, and the other person could have more muscle.

Table 1. Classification of weight based on BMI in adults

\begin{tabular}{lcc}
\hline Classification & $\begin{array}{c}\text { BMI }\left(\mathrm{kg} / \mathrm{m}^{2}\right) \text { in } \\
\text { Caucasian }\end{array}$ & $\begin{array}{c}\text { BMI }\left(\mathrm{kg} / \mathrm{m}^{2}\right) \text { in } \\
\text { Asian }\end{array}$ \\
\hline Underweight & $<18.5$ & $<18.5$ \\
Normal range & $18.5-24.9$ & $18.5-22.9$ \\
Overweight & 25.0 & $\geq 23.0$ \\
Preobese & $25.0-29.9$ & - \\
At risk & - & $23.0-24.9$ \\
Obese I & $30.0-34.9$ & $25.0-29.9$ \\
Obese II & $35.0-39.9$ & $\geq 30.0$ \\
Obese III & 40.0 & - \\
\hline
\end{tabular}

Another way to classify obesity is by measuring waist circumference (WC) and waist-to-hip ratio (WHR). Waist-to-hip ratio is commonly used to measure abdominal obesity. Waist circumference is the minimum measurement between the xiphoid process and the umbilicus, while hip circumference is the maximum measurement, around buttocks posteriorly and the symphysis pubis anteriorly. ${ }^{8}$ Conventionally, central (abdominal) obesity is defined as a WC $\geq 102$ $\mathrm{cm}$ in men and $\geq 88 \mathrm{~cm}$ in women, or WHR $\geq 0.90$ in men and $\geq 0.85$ in women. ${ }^{12}$ Some reports have shown that WC correlated better with intra-abdominal adipose tissue than WHR and BMI, as measured by CT scan and MRI. However, many experts still hold the views that body weight, BMI, WC, and WHR provide complementary information in the assessment of health status and cardiovascular risks. ${ }^{8,13}$

\section{ETIOLOGY}

The three fundamental mechanisms underlying obesity are: ${ }^{14} 1$ ) relative increase in energy intake; 2 ) relative decrease in energy expenditure; and 3) preferential partitioning of ingested calories to fat storage. However, most obesity is a consequence of energy imbalance due to excessive energy intake and (relatively) inadequate energy expenditure. ${ }^{8}$ Increased food intake, particularly dietary fat, is the most often cause of excessive energy input, while reduced energy expenditure is usually due to a sedentary lifestyle with inadequate physical activity. Experiments have shown that obesity is related with various factors; apart from the environmental and lifestyle factors, there are also 
genetic factor (like gene products) and hormones, that are related to obesity. ${ }^{14}$

\section{Environmental and lifestyle factors}

Our environment nowadays is called "obesogenic" environment, ${ }^{7}$ and this means that the environment is likely to induce people to become obese. This term becomes apparent in accordance with the facts in our neighborhood. Growing fast-food restaurants and sophisticated technology all contribute to these facts. Food are easy to get, especially in developed countries and somewhat cheap, but the problem is that the cheapest food is fatty food. ${ }^{4}$ People often eat these kind of "junk food", even in the developing countries this trend seems to rise, and a lot of people world wide are now "saving" fat in their body. More over, the advanced technology, like computer, phone, public transport truly affect society's lifestyle. The more advanced the society, the less they do physical activity, or it can be said that these people are going into sedentary lifestyle, a life with little physical activity. This is not intended to blame either the environment or the obese subject, since obesity is caused by interrelation of many factors. Integrative and comprehensive solutions need to be taken in order to overcome this epidemic.

\section{Genetic and hormonal factors}

It is no doubt that obesity is caused partly by genetic and hormonal disorder. Some genetic mutations have been reported to be the cause of obesity. ${ }^{15,16}$ To date, experts have discovered many peptides, hormones, and cytokines that are related to obesity. This paper will only discuss some of them.

\section{Leptin}

One of the most important discovery in obesity was the identification of a hormone called leptin in $1994 .{ }^{17}$ Leptin is the product of the obesity (ob) gene, a 167amino acid peptide, expressed in white adipose tissue, stomach, placenta and possibly, the mammary gland. ${ }^{14,17,18}$ Leptin has a cytokine-like predicted structure, which includes $4 \alpha$-helices, $2 \beta$-sheets, and a single disulfide bond between cysteine 96 and $146 .{ }^{14}$ In the obese $(o b / o b)$ mouse, a mutation of the leptin gene causes leptin deficiency, ${ }^{17-20}$ and results in hyperphagia, decreased energy expenditure, severe obesity, and insulin-resistant diabetes. ${ }^{20}$ Central or peripheral administration of leptin to these mice leads to acute decrease in food intake and chronic administration of leptin results in marked reduction in body fat.

Leptin is hypothesized to increase thermogenesis, energy expenditure and decrease food intake through satiety signal to the neurons of hypothalamus. ${ }^{14,17-20}$ Leptin decreases food intake and energy expenditure through the signaling pathways of neuropeptide $\mathrm{Y}$ (NPY), pro-opiomelanocortin (POMC) and sympathetic nerve system (SNS). ${ }^{17,21}$ Neuro peptide $\mathrm{Y}$ is a potent stimulator of appetite ${ }^{8}$ and leptin was revealled to inhibity NPY ${ }^{17,21}$ Melanocortins are neuropeptides that are derived from POMC precursor polypeptide; when they are released from the axon terminals in hypothalamus, these peptides reduce food intake, while increasing energy expenditure. ${ }^{21}$ Leptin stimulates POMC and SNS to yield the same effect. ${ }^{17,21}$

High plasma leptin serum indicates high fat mass, since leptin is secreted mainly from adipose tissue. ${ }^{22}$ Leptin is a paradox, considering the physiological effects of leptin to decrease food intake and increase energy expenditure, yet, many obese people had shown to have higher plasma leptin than their lean counterpart. Although some obesity occur because of leptin deficiency, ${ }^{15,16}$ most obesity do not have the same cause. ${ }^{20,22}$ This leads to the notion of leptin resistance, ${ }^{14}$ both in rodents and humans, and leaves us with more mystery concerning obesity that need to be solved.

\section{$\beta 3$-adrenergic receptor and $T N F-\alpha$}

Activation of the $\beta 3$-adrenergic receptors by the SNS leads to increased thermogenesis via brown adipose tissue (BAT), lipolysis in white adipose tissue (WAT), and acute suppression of food intake. ${ }^{8,23} \mathrm{On}$ the other hand, low basal metabolic rate (BMR) is a risk factor for weight gain and obesity. ${ }^{21}$ The polymorphism at codon 64 of the $\beta 3$-adrenergic receptor gene has been suggested to be associated with low BMR. This decreased expression of receptors in adipose tissue has been described in both animals and humans. ${ }^{8}$ Studies on obese Pima Indians, ${ }^{24}$ Finns, ${ }^{21}$ and Danes ${ }^{25}$ have elicited the findings of a missense mutation replacing tryptophan with arginine at codon 64 of the $\beta 3$-adrenergic receptor gene, and it was associated with low BMR, ${ }^{21}$ insulin resistance, ${ }^{25}$ early onset of type 2 Diabetes, ${ }^{24}$ and increased risk of obesity. ${ }^{26}$

Tumor necrosis factor-alpha (TNF- $\alpha$ ) is a cytokine which may be released by adipose tissue, stimulates 
lipolysis, increases insulin resistance, and causes endothelial dysfunction. ${ }^{8,27}$ A positive correlation has been reported between TNF- $\alpha$ mRNA levels in adipose tissue and the level of hyperinsulinemia in obese subjects. $^{8,27,28}$

\section{Ghrelin and Adiponectin}

Ghrelin, a novel endogenous ligand for growth hormone secretagogue (GHS) receptor originally isolated from the stomach, occurs in the hypothalamus arcuate nucleus and may play a role in energy homeostasis, ${ }^{29}$ in addition to long-term regulation of body weight. ${ }^{30}$ This hypothesis is proven by the increase in plasma ghrelin level with diet-induced weight loss. ${ }^{30}$ A study done by Shintani et al provided evidence that ghrelin is an orexigenic peptide that antagonizes leptin action (leptin works via inhibition of NPY pathway) through the activation of hypothalamic NPY receptor pathway. ${ }^{29}$

Adiponectin is another hormone secreted from the adipose tissue. ${ }^{31} \mathrm{~A}$ study showed that decreased adiponectin correlates with insulin resistance in mouse. This situation can be reversed by applying combination of physiological dose of adiponectin and/or leptin. The mRNA expression of adiponectin and its plasma level are significantly reduced in obese/diabetic mice and humans. A research conducted by Yamauchi et $\mathrm{al}^{31}$ indicated that adiponectin acts primarily on skeletal muscle to increase influx and combustion of free-fatty acid (FFA), theraby reducing muscle triglyceride content, thus, this might contribute to the improved insulin signal transduction, as demonstrated by an increase in insulin-induced phosporylation. They concluded that the replenishment of adiponectin might provide a novel treatment for insulin resistance and type 2 diabetes.

\section{THE DANGER OF OBESITY}

There is no doubt that obesity is not a disease without complications. Many other diseases are linked with obesity, and obesity is one of the main risk factor for those diseases. The world trend in epidemiology is now shifting to degenerative diseases like hypertension, CHD, stroke, etc., and obesity contributes largely to the occurrence of these illnesses. This condition is worsened in the developing countries, like Indonesia and other Asian countries, where health care providers are in the state of transition in epidemiology to face both infectious and degenerative diseases. ${ }^{32}$ Mortality is often linked to obesity as a consequence of obesity-related illnesses, and the numbers of such mortality have been incredibly huge.

\section{Obesity and mortality}

Recently, as many as 300,000 Americans die each year from obesity-related illnesses. The number is approaching the 400,000 who died prematurely from cigarette smoking, ${ }^{3}$ and accounts for $37 \%$ of total health costs. ${ }^{8}$ A report in England showed that obesity caused up to 30,000 deaths a year. ${ }^{33}$ The number was not as many as in America, but England also does not have as many population as the US. A cohort study in US has been performed to investigate the correlation between BMI and mortality. ${ }^{34}$ They discovered that the risk of death from all causes, CHD, cancer, or other diseases was increased in moderate to severe overweight men and women in all age groups. This BMI associated risk is greater in whites than in blacks. Overall, obesity is associated with increased mortality in men, and reduced functional status in elderly women, ${ }^{35}$ and weight loss reduces total mortality and other illnesses'-related deaths. ${ }^{11}$ Table 2 summarizes the benefits of $10 \mathrm{Kg}$ weight loss, e.g. to reduce mortality rates. ${ }^{11}$

\section{Obesity and other diseases}

Based on the evidence from the Pima Indians, it takes 15 to 20 years before the increase in body weight is followed by the onset of diabetes. ${ }^{36}$ Metabolic studies suggest that obesity is accompanied by insulin resistance as well as a reduced number of insulin receptors, ${ }^{37}$ thus obesity complicates diabetes because glycemic control, daily oral antidiabetic medications, and insulin needs are affected by the increased resistance. ${ }^{35}$ Many other reports have also confirmed the tight link between obesity and diabetes, especially non insulin dependent diabetes mellitus (NIDDM). Moreover, some studies affirmed the causal relationship between fat distribution and obesity to diabetes. ${ }^{35,37}$ Abdominal obesity is said to be the major risk factor for NIDDM. ${ }^{37}$ Women with BMI 23 and $24 \mathrm{Kg} / \mathrm{m}^{2}$ had a greater risk of diabetes (2.6 times) compared to women with BMI $<22 \mathrm{Kg} / \mathrm{m}^{2}$. It was suggested that the amount of weight gained since early adulthood significantly contributed to the risk of acquiring diabetes in later life. Public health recommendations should be emphasized on the prevention of obesity to reduce the occurrence of NIDDM. ${ }^{11,37}$

Hypertension is one of the most prevalent degenerative disease, which has obesity as one of its major risk 
factors. ${ }^{32}$ Human obesity is mainly marked with elevated plasma leptin serum. ${ }^{14,20,22}$ Most studies showed that leptin and blood pressure was correlated. ${ }^{38}$ In obese humans, the increased level of plasma leptin result in the increase in blood pressure. Furthermore, mean arterial pressure, heart rate, and systolic blood pressure are correlated with plasma leptin. It is important to realize that obesity accounts for $65 \%$ to $75 \%$ of human essential hypertension. ${ }^{38}$ Therefore, understanding the mechanisms by which obesity increases blood pressure is essential. One of the most accepted mechanism is by the activation of the sympathetic nervous system, mainly by the increased level of leptin that stimulates and inhibits some neurochemical pathways in the hypothalamus. ${ }^{38}$ As a result to SNS stimulation, cardiac output and stroke volume are also increased. ${ }^{39}$ Blood pressure is determined by cardiac output and total peripheral resistance. ${ }^{40}$ Elevation of cardiac output contributes to increased blood pressure, even without a rise in peripheral resistance. The renin-angiotensin-aldosterone system which promotes water and sodium tubular reabsorption as well as physical compression of the kidney due to fat stacking may also be important factors in raising blood pressure in obesity. ${ }^{38}$ To get more insight in the underlying physiology of these mechanisms more investigations are needed.

In normal subjects, insulin inhibits lipolysis and the production of very low density lipoprotein (VLDL), and promotes the catabolism of very low density lipoprotein cholesterol (VLDL-C) to high density lipoprotein cholesterol (HDL-C). ${ }^{41}$ Obesity is associated with insulin resistance, characterized particularly by increased triglyceride and VLDL-C, and reduced HDL-C. ${ }^{41}$ Increased triglycerides, LDL, LDL oxidation, and reduced HDL all contribute to increasing atheroma, at the same time, blood coagulability is amplified, which promotes thrombosis. ${ }^{11}$ Statistics showed that the absolute risk of CHD or stroke was much greater for overweight men than for women of the same BMI, ${ }^{11}$ this probably was due to the effect of estrogen in premenopause women. Interestingly, the acceleration of CHD seen in overweight men is only apparent below the age of $50 .{ }^{11}$ In men over 50, more immediate factors (especially smoking which tends to lower weight) dominate the picture. Obesity is now cited as the most important preventable cause of cardiovascular disease after smoking, therefore the prevention and management of obesity may become important steps in preventing it.

Table 2 lists some probable results of having $10 \mathrm{Kg}$ weight loss. ${ }^{11}$ As described above, obesity may complicate and cause some of those diseases, even increase mortality. Studies have shown that weight loss may ameliorate those consequences. Ten kilos of body weight reduction can reverse the conditions and improve health, e.g. to decrease blood pressure, cholesterol, triglyceride, LDL, and increase HDL.

Apart from the metabolic problems created by obesity such as hypertension, NIDDM, and dyslipidemia, other problems such as physical, social, and psychological problems also emerged. Table 3 describes some of these problems, showing the vast range of obesity consequences. ${ }^{11}$ Although they are important and should be taken into account, further detailed explanation of those other problems are beyond the scope of this paper. In addition to the problems listed in table 3 , obesity can increase the risk of some diseases like respiratory disease, ${ }^{11}$ osteoarthritis, gall stones, colon and kidney cancers. ${ }^{2}$ Obesity also causes peripheral sensorimotor and autonomic neuropathic late complications, due to mechanical compression of nerves by adipose mass. ${ }^{35}$

Table 2. Benefit of $10 \mathrm{Kg}$ weight loss

\begin{tabular}{ll}
\hline Mortality & $>20 \%$ fall in total mortality \\
& $>30 \%$ fall in diabetes-related deaths \\
& $>40 \%$ fall in obesity-related cancer deaths \\
Diabetes & Fall of $50 \%$ in fasting glucose \\
Blood pressure & Fall of $10 \mathrm{mmHg}$ in systolic blood pressure \\
& Fall of $20 \mathrm{mmHg}$ in diastolic blood pressure \\
Lipids & Fall of $10 \%$ in total cholesterol \\
& Fall of $15 \%$ in LDL \\
& Fall of $30 \%$ in triglycerides \\
& Increase of $8 \%$ in HDL \\
\hline
\end{tabular}

Table 3. Medical consequences of obesity in men and women

\begin{tabular}{|c|c|c|}
\hline Physical symptoms & Metabolic problems & Social problems \\
\hline $\begin{array}{l}\text { Tiredness } \\
\text { Breathlessness } \\
\text { Varicose veins } \\
\text { Back pain } \\
\text { Arthritis } \\
\text { Edema/cellulites } \\
\text { Sweating/intertrigo } \\
\text { Stress incontinence } \\
\end{array}$ & $\begin{array}{l}\text { Hypertension } \\
\text { NIDDM } \\
\text { Hepatic steatosis } \\
\text { Hyperlipidemia } \\
\text { Hypercoagulation } \\
\text { IHD and stroke }\end{array}$ & $\begin{array}{l}\text { Isolation } \\
\text { Agoraphobia } \\
\text { Unemployment } \\
\text { Family/marital -stress } \\
\text { Discrimination }\end{array}$ \\
\hline $\begin{array}{l}\text { Anesthetic/surgical } \\
\text { problems }\end{array}$ & Endocrine problems & $\begin{array}{l}\text { Psychological } \\
\text { problems }\end{array}$ \\
\hline $\begin{array}{l}\text { Sleep apnea } \\
\text { Chest infections } \\
\text { Wound dehiscence } \\
\text { Hernia } \\
\text { Venous thrombosis }\end{array}$ & $\begin{array}{l}\text { Hirsutism } \\
\text { Oligomenorrhea/infertility } \\
\text { Metromenorrhagia } \\
\text { Estrogen-dependent cancers: } \\
\text { breast, uterus, prostate }\end{array}$ & $\begin{array}{l}\text { Low self-esteem } \\
\text { Self deception } \\
\text { Cognitive disturbance } \\
\text { Distorted body image } \\
\text { Depression }\end{array}$ \\
\hline
\end{tabular}

$\mathrm{NIDDM}=$ Non insulin dependent diabetes mellitus, IHD = Ischemic heart disease 


\section{TREATMENT}

Obesity is caused by positive energy homeostasis, due to more energy intake through diet and less energy expenditure. It is said that lifestyle and behavioral modification are primary ways in reducing weight. ${ }^{8}$ Pharmacological and surgical intervention are used whenever the above measures have failed in treating obesity, especially in subjects who have an illness and significant health risks for other diseases' complications. On the other hand, medication without improvement of lifestyle is less effective, due to the regaining of weight after the cessation of medication or after a certain period of time. ${ }^{2,8}$

\section{Lifestyle}

Weight reduction often is not an easy task both for patients and physicians. Many patients feel depressed when they have to achieve a desirable weight goal, even some patients are "punished" by their doctors for not being able to achieve the goal. ${ }^{42}$ This problem should not happen if there is a good cooperation between both sides, accompanied by a well-applied weight management. Once a desirable body weight is reached, the task is not finished yet, as the next assignment is to maintain the reduced weight in a healthy level. Overall, regarding the hard effort to reduce and maintain weight, it is easier to prevent weight gain and obesity by lifestyle interventions, namely diet, physical activity, and behavioral modification. $^{2}$ These well applied interventions also minimize the need to use other kinds of treatment such as pharmacological and surgical.

\section{Diet}

Diet should be considered not merely how and what we eat to loss weight, but should be stressed on the management of eating to get better health condition. In case of obesity, diet is intended to lose weight as much as possible to achieve the level of safest weight reduction. It is advised to have a balance diet with an energy deficit of 500-600 kcal/day, ${ }^{2}$ since the problem of obesity is excess of energy intake. Diet in this case is important to limit energy intake. Among the major nutrition substances (carbohydrate, fat and protein), fat yields the most calories per gram $(9.3 \mathrm{Kal} / \mathrm{g})$, while protein and carbohydrate only about $4.1 \mathrm{Kal} / \mathrm{g}$. Hence, reduction in dietary fat can be an easier way of achieving the required energy intake reduction. ${ }^{10} \mathrm{~A}$ study concerning the effect of behavioral intervention focusing on either calorie restriction or calorie plus fat restriction on NIDDM patients to lose weight was conducted. ${ }^{43}$ They suggested that using the combination of calorie and fat restriction might help to reduce weight better than calorie restriction alone.

Although a sudden drop of body weight is sometimes unnecessary and hard to achieve, a $5-10 \mathrm{Kg}$ of weight reduction has been suggested to improve health condition, as stated in table 2. Apparently, for patients with morbid obesity and complications, a significant weight loss in a short time is crucial, and this can be achieved by using a very low calorie diet. Situations in which very low calorie diet may be useful are listed in table $4 .{ }^{42}$

Table 4. Very low calorie diets and thei benefits

Morbid obesity (BMI $>40 \mathrm{~kg} / \mathrm{m}^{2}$ )

Significant weight loss may make physical activity possible

\section{NIDDM requiring insulin therapy}

Significant weight loss may improve control of diabetes and prevent the initiation of insulin therapy

\section{Ischemic heart disease}

Weight reduction may allow easier access for surgical intervention, but alone may diminish the need for surgery.

\section{Severely debilitating arthritis}

Weight loss can help improve mobility (weight gain is often seen as secondary cause of a marked reduction in physical activity)

BMI $=$ Body mass index

There is no doubt that maintaining good eating behavior needs a discipline, especially when one is expected to change his/her eating habits. One of the simplest and most necessary measure is to reintroduce the habit of eating three times a day, and only three times a day: sitting down, from a plate, always have proper meals, no eating with fingers, and be prepared to spend a little more on quality and little less on quantity. ${ }^{11}$

\section{Physical activity}

A reduction in food intake alone is seldom effective, unless accompanied by some daily physical activities to increase energy expenditure. Moreover, physical activities contribute significantly to weight reduction and other benefits in mood, fitness and cardiopulmonary functions, and insulin sensitivity. ${ }^{2,11}$ Increasing physical activity or exercise becomes crucial during weight maintenance. ${ }^{42}$ Simple interventions in behaviour, such as walking (rather than driving) short 
distances, walking up stairs (rather than using lifts or elevators), or cycling for recreation (rather than sedentary activities), need to be emphasized. In general, it is more important for the patients to increase overall physical activity than simply try to exercise regularly.

Physical activity should be adjusted to individual's age, physical fitness and any pre-existing morbidity. ${ }^{2}$ For example, for obese-hypertensive patients, it is recommended to do aerobic exercise (endurance training) rather than anaerobic exercise (resistance training), because resistance training can elevate blood pressure drastically as a result of increased intrathoracal pressure (valsava maneuver). ${ }^{44}$ Jogging, swimming, cycling and tread milling are some of the examples of aerobic exercise that can be done in or out door. It is recommended to do these exercises 3-5 times a week, 20-60 minutes, with intensity of 50\%$80 \%$ of maximal pulse rate (220-age). ${ }^{45}$ Normally, exercise can be useful when practice regularly and adjusted to patient's condition.

\section{Behavioral modification}

In many cases, overweight and obesity are not the consequence of a simple lack of knowledge. As with many health-related behaviors, there are social, emotional and other factors that can over-ride correct information. ${ }^{2}$ This signifies the importance of psychosocial factors in the development and maintenance of obesity. ${ }^{46}$ In turn, obesity carries great psychosocial cost to the sufferer, such as depression, reduced quality of life and self-esteem, poorer school/work performance, etc. Therefore, psychosocial interventions are important adjuncts in the multi-modal treatment in obesity. Behavioral interventions are mainly aimed to change eating and activity habits, with the aim to increase patients' life quality. Guidance on meal frequency, pace of eating, avoiding situations where there is a tendency to overeat, and separation of eating from other activities through behavioral therapy can result in weight loss. ${ }^{2}$ Main components of the therapy include: self-monitoring and record keeping, habit breaking, stimulus control, modification of eating style, reinforcement of desirable behaviors, and impulse or self-control strategies. ${ }^{46}$

\section{Pharmacological intervention}

At the moment, medical world are looking for long term 'antiobesity' drugs which are safe and effective.
Those drugs can be divided mainly into two groups: anorexic agents that decrease energy storage and act on the central nervous system (CNS), and another group that increases energy expenditure and acts on the gastrointestinal (GI) tract. ${ }^{2,8,12}$

\section{CNS-acting drugs}

Anorexic agents usually act centrally on the noradrenergic or serotonergic systems. Drugs that mimic serotonine suppress appetite that lead to reduced food intake, and may also increase thermogenesis. ${ }^{8,47}$ There are several drugs in this category. One of them is Ddexfenfluramine, a serotonine uptake inhibitor, that has been shown to be effective in reducing weight. However, it was recently withdrawn due to reported side effects. ${ }^{2,8}$ Such side effects are primarily associated with pulmonary hypertension and cardiac valvular lesions. ${ }^{2,8,42}$ The lesions are comparable to those seen in patients with carcinoid syndrome and are thought to be due to elevated levels of serotonin. ${ }^{42}$ Phentermine, diethylpropion, mazindol, and ephedrine are centrally acting noradrenergic or dopaminergic agents which suppress appetite by stimulating release of catecholamines from storage sites in the CNS., ${ }^{2,8,42}$ They have limited acceptability due to CNS side effects such as insomnia, nervousness, agitation, heart palpitation, and dry mouth., ${ }^{2,42}$ Another reasons for the less acceptability of these drugs are frequent regain of weight after medication cessation or when there is repetition of the "usual" eating and activity patterns. ${ }^{42}$

A novel member of the group, cyclobutanemethanamine hydrochloride, has recently been listed in Australia. It acts through both the serotonergic and noradrenergic pathways, as a selective serotonine (SSRI) and noradrenaline (SNRI) reuptake inhibitor. ${ }^{2,7,8,42,47,48}$ It decreases weight by enhancing satiety (suppressing appetite), thus, reducing food intake, showing a $\beta 3$ adrenergic agonistic effect. Furthermore, it increases thermogenesis and metabolism. ${ }^{2,12,42,47,48}$

It is recommended that cyclobutanemethanamine $\mathrm{HCl}$ should not be used in patients with anorexia nervosa, uncontrolled hypertension, and those with a history of coronary artery disease, congestive heart disease, arrhythmia, stroke, or severe renal or hepatic impairment. Pregnant and lactating women are not recommended to use this drug. ${ }^{48}$ Despite dry mouth, anorexia, insomnia, constipation and headache as its adverse effects, cyclobutanemethanamine $\mathrm{HCl}$ was well tolerated in many studies. ${ }^{47,48}$ 
The recommended dose is $10-15 \mathrm{mg}$ daily. ${ }^{48}$ After 12 months, 150 cyclobutanemethanamine $\mathrm{HCl}$ treated obese patients lost $5-10 \%$ of their initial body weight, accompanied by a decrease in waist circumference, serum triglyceride, serum uric acid, and blood glucose levels, and an increase in HDL levels. ${ }^{47}$ Some studies indicated that cyclobutanemethanamine $\mathrm{HCl}$ elevated blood pressure, but some reported no changes in blood pressure. Overall, cyclobutanemethanamine $\mathrm{HCl}$ is well tolerated in controlled hypertensive patients. $^{47}$

\section{GI tract-acting drugs}

Tetrahydrolipstatin is a new drug that yields its effect through intervention on peripheral organs, and to date, it is the only drug of this kind. It inhibits gastric, ${ }^{7}$ intestinal, ${ }^{49}$ and pancreatic ${ }^{8}$ lipase. These lipases are responsible for the breakdown of triglycerides into fatty acid and monoglyceride that are then absorbed by the intestines' mucosal cells. By inhibiting the lipases, tetrahydrolipstatin can reduce fat absorption by about $30 \%$, with non-absorbed triglycerides being excreted in the feces, thus, it decreases energy storage which is important to treat obesity. ${ }^{7,8,49}$

This drug is not intended for use in children, women during pregnancy or lactation. ${ }^{49}$ Other contraindications include malabsorption or cholestasis, or hypersensitivity to the drug or agents used in its formulation. No major adverse effects have ever been reported. ${ }^{49}$ The potential drawbacks to its usage are adverse mild to moderate GI effects ${ }^{49}$ such as oily spotting per rectum, flatus with discharge, fecal urgency, fatty/oily feces, ${ }^{2}$ and frequent stool and flatulence. ${ }^{42}$ The drug can reduce absorption of fat-soluble vitamins (A,D,E,K) but plasma concentrations remain within normal range with no apparent clinical manifestations of vitamin deficiency. Specific vitamin supplementation is unnecessary as long as the patient's vitamins dietary intake is adequate. ${ }^{2}$

The drug $(120 \mathrm{mg})$ should be taken at the time of each main meal, or within 1 hour, but it needs not to be taken if meal is skipped or contains no fat. ${ }^{49}$ Use of the drug in adjunct to dietary and other lifestyle intervention has been proved to prevent or delay glucose intolerance or type 2 diabetes in obese subjects. ${ }^{50}$ Further studies with larger number of participants concerning this drug and other antiobesity drugs need to be carried out in order to discover the best method of pharmacological interventions to treat obesity.

\section{Surgery}

Another way to loose weight fast is through surgical intervention. This method is appropriate for morbidly obese patients with BMI $>40$ or $>35$ if there are other associated cardiovascular risk factors, or for whom all other techniques have failed. ${ }^{2,72}$ Because of the expense and risk, surgical intervention usually represents a last resort in weight loss therapy. ${ }^{7}$ Another discouragement of this method is because its tendency for rebound weight gain as a result of rapid physiological adjustments. Nevertheless, recent findings have showed the efficacy of surgery to help obese patients having large and quick weight losses in addition to improving their quality of life..$^{2,730,48}$

Surgical intervention in the form of gastroplasty or gastric bypass can result in more than $>30 \mathrm{Kg}$ of weight loss. Moreover, glycemic control was improved in obese diabetics, and the incidence of diabetes and the prevalence of hypertension also fell following gastric bypass surgery. ${ }^{2}$ The bypass is associated with markedly suppressed ghrelin levels, possibly contributing to the weight-reducing effect of the procedure. ${ }^{30}$ Ghrelin is hypothesized to have a role in long-term regulation of body weight. Normally, plasma ghrelin increases before meal and after dietinduced weight loss. Gastric bypass contributes to weight reduction by disrupting ghrelin secretion by isolating ghrelin-producing cells from direct contact with ingested nutrients, which normally regulate ghrelin levels. More recent laparoscopic banding technique, which necessitates modifications to food intake through adjustment of an expandable cuff around the lower esophageal sphincter, has become the most common procedure, with food intake long term outcomes. ${ }^{7}$ This method also allows better control of postoperative weight loss. ${ }^{42}$

Even though lifestyle modifications are the primary ways to deal with obesity problems, for some people, it is useful to achieve the wanted goal through lifestyle changes together with drug therapy (if necessary), and to look to surgical techniques to help weight maintenance. ${ }^{42}$

In conclusion, medical world should view obesity as a disease and a spreading epidemic. Obesity has increased in prevalence almost in every part of the world, especially during the last decade. The increased number of obesity-related diseases, such as cardiovascular disease, hypertension and diabetes has also ultimately lead to mortality. Etiology of obesity 
is so complex, a combination of multi factors of genetics, environment and behavior. Although it seems hard to overcome this matter, patients and doctors should have a strong intention to achieve a goal, set with the purpose of weight loss of 5 to $10 \%$, that might effect in substantial benefits. Dietary and lifestyle modifications remain the primary method in dealing with the problem. This measures might be accompanied by pharmacological and surgical intervention whenever needed, so that most effective results can be achieved. Patients should consult their physicians in order to decide which methods are the most needed and effective to find the solutions to combat obesity. The time has come where doctors and patients globally should be aware of the menace of obesity; the key to defeating it is by prevention. If we wait until it mounts up, it will be too late for the world.

\section{REFERENCES}

1. Wichelgren I. Obesity: how big a problem. Science 1998;280:1364-6.

2. Ooi CG, Hew FL. Obesity: the epidemic of the millennium. Med Prog 2001;28(9):11-6.

3. Bonnetta L. Scientists battle obesity overload. Nat Med 2001;7:387.

4. Frankish H. Obesity and diabetes epidemics show no sign of abating. Lancet 2001;358:896.

5. Taubes G. As obesity rates rise, experts struggle to explain why. Science 1998;280:1367-8.

6. Soegondo S. Obesitas dan Permasalahannya. In: Lesmana LA, Jacoeb TNA, Sjarif DR, Gunardi H, Setiati S, Alwi I, editors. Prosiding Simposium Temu Ilmiah Akbar; 2002 April 11-14; Jakarta, Indonesia. Jakarta: Pusat Informasi dan Penerbitan IPD; 2002.p65.

7. Egger G, Binns A. A model approach to obesity. Med Prog 2002;29(4):8-13.

8. Ko GTC, Cockram CS, Critchley JAJH, Chan JCN. Obesity-definition, aetiology, complications and treatment. Med Prog 1999;26(8):10-4.

9. Cotran ES, Koman V, Collins T. Robbins Pathologic Basis of Disease. $6^{\text {th }}$ ed. Philadelphia: Saunders; 1999.

10. World Health Organization. The Asia-Pacific Perspective: redefining obesity and its treatment. Australia: WHO; 2000.

11. Lean M. Helping the obese man lose weight. Med Prog 2002;29(3):9-12.

12. Bray GA. Obesity: a time bomb to be defused. Lancet 1998;352:160-1.

13. Janssen I, Heymsfield SB, Allison DB, Kotler DP, Ross $R$. Body mass index and waist circumference independently contribute to the prediction of nonabdominal, abdominal subcutaneous, and visceral fat. Am J Clin Nutr 2002;75:683-8.

14. Pawitan JA. Genetic factors associated with susceptibility to obesity. Med J Indones 1999;8:222-7.
15. Montague CT, Farooqi IS, Whitehead JP, Soos MA, Rau $\mathrm{H}$, Warenham NJ, et al. Congenital leptin deficiency is associated with severe early-onset obesity in humans. Nature 1997;387:903-7.

16. Chua SC, White DW, Wu-Peng XS, Liu SM, Okada N, Kershaw EE, et al. Phenotype of fatty due to Gln269Pro mutation in the leptin receptor (lepr). Diabetes 1996;45:1141-3.

17. Bray GA, York DA. Leptin and clinical medicine: A new piece in the puzzle of obesity. J Clin Endocrin and Metab 1997;82:2771-6.

18. Mantzoros CS. The role of leptin in human obesity and disease: A review of current evidence. Ann Intern Med 1999;130:671-80.

19. Caro JF, Sinha MK, Kolaczynski JW, Zhang PL, Consicine RV. Leptin:the tale of an obesity gene. Diabetes 1996;45:1455-62.

20. Havel PJ. Leptin production and action: relevance to energy balance in humans. Am J Clin Nutr 1998;67:355-6.

21. Sipilainen R, Uusitupa M, Heikkinen S, Rissanen A, Laalso M. Polymorphism of the $\beta 3$-adrenergic receptor gene affects basal metabolic rate in obese Finns. Diabetes 1997; 46:77-80

22. Klein S, Coppack SW, Ali VM, Landt M. Adipose tissue leptin production and plasma leptin kinetics in humans. Diabetes 1996;45:984-7.

23. Mantzoros CS, Qu D, Frederich RC, Susulic VS, Lowell BB, Flier EM. Activation of $\beta 3$ adrenergic receptors suppresses leptin expression and mediates a leptinindependent inhibition of food intake in mice. Diabetes 1996;45:909-14.

24. Walston J, Silver K, Bogardus C, Knowler W, Celi F, Austin S, et al. Time of onset of non-insulin dependent diabetes mellitus and genetic variation in the $\beta 3$ adrenergic receptor gene. N Engl J Med 1995;333:343-7.

25. Urhammer SA, Clausen JO, Hansen T, Pedersen O. Insulin sensitivity and body weight changes in young white carriers of the codon 64 amino acid polymorphism of the $\beta 3$-adrenergic receptor gene. Diabetes 1996; 45:1115-20.

26. Arner P. The $\beta 3$-adrenergic receptor: a cause and cure of obesity? N Engl J Med 1995;333:382-3.

27. Kirchgessner TF, Uysal KT, Wiesbrock SM, Marino MW, Hotamisligil GS. Tumour necrosis factor-alpha contributes to obesity-related hyperleptinemia by regulating leptin release from adipocytes. J Clin Invest 1997;100:2777-82.

28. Grunfeld C, Zhao C, Fuller J, Pollock A, Moser A, Friedman $\mathrm{J}$, et al. Endotoxin and cytokines induce expression of leptin, the ob gene product, in hamsters. $\mathbf{J}$ Clin Invest 1996;97:2152-7.

29. Shintani M, Ogawa Y, Ebihara K, Abe MA, Miyanaga F, Takaya K, et al. Ghrelin, an endogenous growth hormone secretagogue, is a novel orexigenic peptide that antagonizes leptin action through the activation of hypothalamic neuropeptide Y/T1 receptor pathway. Diabetes 2001;50:227-32.

30. Cummings DE, Weigle DS, Frayo RS, Breen PA, Marina $\mathrm{K}$, Dellinger EP, et al. Plasma ghrelin levels after dietinduced weight loss or gastric bypass surgery. N Engl J Med 2002; 346:1623-30. 
31. Yamauchi T, Kamon J, Terauchi Y, Kubota N, Hara K, Mori $\mathrm{Y}$, et al. the fat-derived hormone adiponectin reverses insulin resistance associated with both lipoatrophy and obesity. Nat Med 2001;7:941-6.

32. Basuki B. Age, body posture, daily working loads, past anti hypertensive drugs and risk of hypertension: A rural Indonesia study. Med J Indones 2000;10:29-33.

33. Vaas A. Obesity causes 30000 deaths a year, report says. Br Med J 2002;324:192.

34. Calle EE, Thun MJ, Petrelli JM, Rodriguez C, Heath CW. Body Mass Index and mortality in a prospective cohort of US adults. N Engl J Med 1999;341:1097-105.

35. Straub RH, Thum M, Hollerbach C, Palitzch KD, Scholmerich J. Impact of obesity on neuropathic late complications in NIDDM. Diabetes Care 1994;17:1290-4.

36. Ravussin E. Energy metabolism in obesity: studies in the Pima Indians. Diabetes Care 1993;16(suppl 1):232-8.

37. Chan JM, Rimm EB, Colditz GA, Stamper MJ, Willett WC. Obesity, fat distribution, and weight gain as risk factors for clinical diabetes. Diabetes Care 1994;17:961-9.

38. Hall JE, Hildebrandt DA, Kuo J. Obesity hypertension: Role of leptin and sympathetic nervous system. Am J Hypertension 2001;14:103S-15S.

39. Lip PL. Pathogenesis of hypertension: current concepts. Med Prog 1994;21(3):5-9.

40. Sherwood L. Human physiology from cells to systems. $4^{\text {th }}$ ed. Pacific Grove: Brooks/Cole; 2001.

41. Williams B. Insulin resistance: the shape of things to come. Lancet 1994;344:521-4.
42. Marks S. Weight management: What GPs need to know. Med prog 1998;25(3):15-20.

43. Pascale RW, Wing RR, Butler BA, Mullen M, Bononi P. Effects of a behavioral weight loss program stressing calorie restriction versus calorie plus fat restriction in obese individuals with NIDDM or a family history of diabetes. Diabetes Care 1995;18:1241-8.

44. MacKnight JM. Hypertension in athletes and active patients. The Physician and Sportsmedicine 1999; 27(4):35-44.

45. Stewart KJ, Exercise guidance in hypertension. The Physician and Sportsmedicine 2000;28(10):81-2.

46. Ung EK. The psychological management of obesity. Med Prog 2002;29(4):17-25.

47. McMahon FG, Fujioka K, Singh BN, Mendel CM, Rowe E, Rolston K, et al. Efficacy and safety of Sibutramine in obese white and African American patients with hypertension. Ach Intern Med; 2000; 160:2185-91.

48. Leung WYS, Thomas GN, Tomlinson B, Critchley JAJH. Sibutramine for the treatment of obesity. Med Prog 2001;28(9):41-7.

49. Thomas GN, Critchley JAJH, Tomlinson B. The lipase inhibitor, orlistat, for the treatment of obesity. Med Prog 2000;27(7):37-40.

50. Heymsfield SB, Segal KR, Hauptman J, Lucas CP, Boldrin MN, Rissanen A, et al. Effects of weight loss with orlistat on glucose tolerance and progression to type 2 diabetes in obese adults. Arch Intern Med 2000; 160:1321-6. 